Mal. J. Microbiol. Vol 3(1) 2007, pp. 7-13

http://dx.doi.org/10.21161/mjm.00207

\title{
Comparison of methods for isolating high quality DNA and RNA from an oleaginous fungus Cunninghamella bainieri strain 2a1
}

\author{
Noor Adila, A.K., Farah Diba, A.B., Zamri, Z., Wan Mohtar, W.Y., Aidil, A.H., Mahadi, N.M. and Murad, A.M.A.* \\ School of Biosciences and Biotechnology, Faculty of Science and Technology, Universiti Kebangsaan Malaysia, 43600 \\ Bangi, Selangor, Malaysia. \\ E-mail: munir@pkrisc.cc.ukm.my
}

\begin{abstract}
A number of protocols have been reported for efficient fungal DNA and RNA isolation. However, many of these methods are often designed for certain groups or morphological forms of fungi and, in some cases, are species dependent. In this report, we compared four published protocols for DNA isolation from a locally isolated oleaginous fungus, Cunninghamella bainieri strain 2a1. These protocols either involved the use of polyvinyl pyrrolidone (PVP), hexacetyltrimethylammonium bromide $(C T A B)$ or without using PVB or CTAB. For RNA isolation, we tested two published protocols, one of which is based on TRI REAGENT (Molecular Research Center, USA) and another is simple method employing phenol for RNA extraction and $\mathrm{LiCl}$ for precipitation. We found that the protocol involving the use of CTAB produced the highest genomic DNA yield with the best quality compared to other protocols. In the presence of CTAB, unwanted polysaccharides were removed and this method yielded an average amount of $816 \pm 12.2 \mu \mathrm{g}$ DNA/g mycelia with UV absorbance ratios $A_{260 / 280}$ and $A_{260 / 230}$ of $1.67 \pm 0.64$ and $1.97 \pm 0.23$, respectively. The genomic DNA isolated via this protocol is also suitable for PCR amplification and restriction enzyme digestion. As for RNA isolation, the method involving phenol extraction and $\mathrm{LiCl}$ precipitation produced the highest yield of RNA with an average amount of $372 \pm 6.0 \mu \mathrm{g} \mathrm{RNA} / \mathrm{g}$ mycelia. The RNA appears to be relatively pure since it has UV absorbance ratios $A_{260 / 280}$ and $\mathrm{A}_{260 / 230}$ of $1.89 \pm 2.00$ and $1.99 \pm 0.03$, respectively. Finally, we have demonstrated that this method could produce RNA of sufficient quality for RT-PCR that amplified a $600 \mathrm{bp}$ fragment of $\Delta 12$-fatty acid desaturase gene in $C$. bainieri.
\end{abstract}

Keywords : Cunninghamella bainieri, DNA extraction, RNA extraction.

\section{INTRODUCTION}

An oleaginous Zygomycetes, Cunninghamella bainieri strain $2 \mathrm{a} 1$, is a promising producer of gamma-linoleneic acid (GLA: 18:3). This strain, which was first isolated from Malaysian forest soil, was shown to produce up to $35 \%$ of its dry weight as lipid and approximately $11 \%$ of total fatty acids are made up of GLA (Ferjani et al., 2005). GLA is considered as an essential fatty acid in humans and acts as an important intermediate in the biosynthesis of biologically active prostaglandin from linolenic acid. It has been reported to be effective for the prevention or curing of cardiovascular diseases, hyper-cholestromia, menstrual disorders as well as a variety of other diseases (Fan and Chapkin, 1998). At present, the principal sources of GLA are the seeds of evening primrose (Oenothera biennis), borage seeds (Borago oficinalis) and black currant seeds (Ribes nigrum) (Lawson and Hughes, 1988). However, the productivity of GLA from these seed oil is considered low, since both a long period and huge area for plant cultivation are required. To overcome these limitations, other organisms such as microorganisms may serve as an alternative for GLA production. Microorganisms have several advantages over plants in the production of GLA including high growth rate, simple culture conditions, independence of seasonal and climatic changes and can

\section{*Corresponding author}

be readily grown under controlled conditions with nutritional regimes that may stimulate or repress the key steps of fatty acid formation (Certik and Shimizu, 1999). In addition, oleaginous microbes provide useful models for studying the genetic and biochemistry of lipid production due to their relatively simpler genetic make-up and the presence of less complex multicellular system as compared to higher eukaryotes.

Isolation of high purity and intact nucleic acids are critical steps for a number of molecular techniques. Isolation of good quality DNA is essential for techniques such as polymerase chain reaction (PCR), Southern blotting and genomic DNA library construction. Similarly, high purity and intact RNA are critical for molecular techniques that are designed for gene expression studies such as reverse transcriptase-polymerase chain reaction (RT-PCR), northern blot analysis, real-time RT-PCR and microarray analysis. The problems that are normally associated with nucleic acid isolation in fungi are the presence of high polysaccharide contaminants, tough cell walls and high level of intracellular ribonuclease (Mukhtar et al., 1998; Al-Samarrai and Schmid, 2000). A number of protocols have been established for fungal DNA and RNA isolation. However, many of these protocols are apparently suitable for certain groups or morphological forms of fungi but may not be versatile and efficient for extracting nucleic acids from other fungal groups or 
morphological forms (Sokolovsky et al., 1990; Mukhtar et al., 1998; Bolano et al., 2001). Hence, identifying and optimising the best protocol that produces the highest quality and quantity of nucleic acids is essential when working with a new fungal isolate.

In this study, we demonstrate the efficiency of published protocols for DNA and RNA isolation from the mycelia of $C$. bainieri strain 2a1. We compared four fungal DNA isolation protocols that were described by Pich and Schubert (1993), Kim et al. (1997), Weiland (1997) and Voigt et al. (1999). For RNA isolation, we compared two protocols, the protocol of Sokolovsky et al. (1990) and the commercial RNA isolation protocol using TRI REAGENT solution from Molecular Research Center, USA. The results of this work will assist us in identifying the best nucleic acid extraction protocol for further molecular genetic studies of this oleaginous fungus.

\section{MATERIALS AND METHODS}

\section{Fungal strain and cultivation}

The fungus $C$. bainieri strain $2 a 1$ was isolated from forest soil (Hamid et al., 2001) and maintained on a Potato Dextrose Agar (Oxoid, USA) at $30{ }^{\circ} \mathrm{C}$ and subcultured weekly. For each experiment, the starter culture was $C$. bainieri mycelia taken from seven-day old culture grown on Potato Dextrose Agar (PDA; Oxoid, United Kingdom). Approximately $1 \mathrm{~cm}^{2}$ pieces of mycelia excised from the PDA plates were sub-cultured into $250 \mathrm{~mL}$ of nitrogen limited media (Kendrick and Ratledge, 1992) containing $3 \%$ glucose, $0.15 \%$ yeast extract and $0.2 \%$ ammonium tartarate, incubated on an orbital shaker $(250 \mathrm{rpm})$ at 30 ${ }^{\circ} \mathrm{C}$ for 3 days. The mycelia were then harvested by filtration, frozen with liquid nitrogen and stored at $-80{ }^{\circ} \mathrm{C}$ until further usage. Before proceeding with nucleic acid extraction, the frozen mycelia were placed in a mortar which was chilled with liquid nitrogen. The frozen sample was ground with a pestle and liquid nitrogen was added to prevent the sample from thawing. Approximately $0.1 \mathrm{~g}$ of fine powder produced was used as starting material for subsequent experiments.

\section{DNA isolation}

\section{DNA extraction employing PVP (Kim et al., 1997)}

The powdered mycelium was mixed with $300 \mu \mathrm{L}$ of extraction buffer ( $250 \mathrm{mM} \mathrm{NaCl}, 25 \mathrm{mM}$ EDTA, $0.5 \%$ SDS, $200 \mathrm{mM}$ Tris- $\mathrm{HCl} \mathrm{pH} \mathrm{8.0)} \mathrm{and} \mathrm{incubated} \mathrm{at} \mathrm{room}$ temperature for $1 \mathrm{~h}$. Freshly prepared polyvinylpyrrolidone (PVP: Sigma, USA) was added to a final volume of $6 \%$ followed by the addition of one half volume of $7.5 \mathrm{M}$ ammonium acetate. The mixture was incubated on ice for $30 \mathrm{~min}$ and centrifuged for $10 \mathrm{~min}\left(13,000 \mathrm{rpm}\right.$ at $\left.4{ }^{\circ} \mathrm{C}\right)$. The supernatant was transferred to a fresh tube and one volume of isopropanol was added. The mixture was left at $-20{ }^{\circ} \mathrm{C}$ for $30 \mathrm{~min}$ to precipitate the DNA. After centrifugation at $13,000 \mathrm{rpm}$ at $4{ }^{\circ} \mathrm{C}$ for $10 \mathrm{~min}$, the pellet was resuspended in $500 \mu \mathrm{L}$ TE buffer $(10 \mathrm{mM}$ Tris- $\mathrm{HCl} \mathrm{pH}$
8.0, $0.1 \mathrm{mM}$ EDTA) and $2 \mu \mathrm{L}$ of RNase $\mathrm{A}(1 \mathrm{mg} / \mathrm{mL})$ was added and incubated at $37^{\circ} \mathrm{C}$ for $15 \mathrm{~min}$. Subsequently, one volume of chloroform: isoamylalcohol (24:1) was added and the mixture was emulsified by inverted shaking. After centrifugation, the supernatant was transferred into a new tube, whereby, one volume of isopropanol was added and the tube was kept at $-20{ }^{\circ} \mathrm{C}$ for $10 \mathrm{~min}$. The mixture was centrifuged and the pellet was washed with $80 \%$ ethanol, dried and dissolved in 20 $\mu \mathrm{L}$ of distilled water.

\section{DNA extraction employing PVP and multiple precipitation steps (Pich and Schubert, 1993)}

The frozen mycelial powder was gently dispersed into three volumes $(\mathrm{w} / \mathrm{v})$ of extraction buffer containing 500 $\mathrm{mM} \mathrm{NaCl}, 50 \mathrm{mM}$ Tris- $\mathrm{HCl}$ (pH 8.0), $50 \mathrm{mM}$ EDTA and 1\% $(\mathrm{v} / \mathrm{v})$ freshly prepared $\beta$-mercaptoethanol. The mycelia were thawed and ice cold $20 \%$ stock solution of PVP was added to a final concentration of $6 \%$. The lysate was kept on ice after thawing. Solid SDS was then added to a final concentration of $2 \%(\mathrm{w} / \mathrm{v})$. The extract was slightly mixed and incubated in a water bath at $65{ }^{\circ} \mathrm{C}$ for $10 \mathrm{~min}$. Subsequently, $1 / 10$ volume of $5 \mathrm{M}$ potassium acetate was added followed by $30 \mathrm{~min}$ incubation on ice and centrifugation $\left(13,000 \mathrm{rpm}, 4{ }^{\circ} \mathrm{C}\right.$ for $\left.10 \mathrm{~min}\right)$. The supernatant was transferred to a new tube and $5 \mu \mathrm{L}$ of RNase $A(10 \mathrm{mg} / \mathrm{mL})$ was added and incubated at $37{ }^{\circ} \mathrm{C}$ for $30 \mathrm{~min}$. The mixture was then mixed with 0.6 volume of isopropanol, incubated on ice for $10 \mathrm{~min}$ and centrifuged for $10 \mathrm{~min}\left(13,000 \mathrm{rpm}\right.$ at $\left.4{ }^{\circ} \mathrm{C}\right)$. The resulting pellet was dried and dissolved in $500 \mu \mathrm{L} 1 \mathrm{X}$ TE $(\mathrm{pH}$ 8.0) and extracted with one volume of phenol-chloroformisoamylalcohol (25:24:1). After centrifugation $(13,000 \mathrm{rpm}$, $10 \mathrm{~min}, 4^{\circ} \mathrm{C}$ ), the aqueous phase was transferred into a new tube and precipitated in one volume of isopropanol $\left(20{ }^{\circ} \mathrm{C}, 5 \mathrm{~min}\right)$. Finally, the tube was centrifuged $(13,000$ $\mathrm{rpm}, 4{ }^{\circ} \mathrm{C}$ for $\left.10 \mathrm{~min}\right)$. The resulting pellet was washed in $70 \%$ ethanol, air dried and dissolved in distilled water. The DNA was stored at $-20^{\circ} \mathrm{C}$ until further usage.

\section{DNA extraction employing CTAB (Voigt et al., 1999)}

Grounded mycelia was resuspended in $700 \mu \mathrm{L}$ of hexacetyltrimethylammonium bromide (CTAB; Sigma Chemicals, USA) extraction buffer [100 mM Tris- $\mathrm{HCl}(\mathrm{pH}$ 8.4), 1.4 M NaCl, $25 \mathrm{mM}$ EDTA, $2 \%$ CTAB] and vortexed for $10 \mathrm{sec}$. The homogenate was incubated at $65^{\circ} \mathrm{C}$ for $10 \mathrm{~min}$. Following extraction, an equal volume of chloroform was added to the mixture, vortexed for $5 \mathrm{sec}$ and then spun for $10 \mathrm{~min}$ at $13,000 \mathrm{rpm}$ and $4{ }^{\circ} \mathrm{C}$. Subsequently, $500 \mu \mathrm{L}$ portion of the upper phase was transferred into a new $1.5 \mathrm{~mL}$ tube and $5 \mu \mathrm{L}$ of RNase A $(20 \mathrm{mg} / \mathrm{mL}$ ) was added to the tube. The mixture was incubated at $37^{\circ} \mathrm{C}$ for $30 \mathrm{~min}$. DNA was precipitated with an addition of equal volume $-20^{\circ} \mathrm{C}$ isopropanol and kept for $15 \mathrm{~min}$ at $-20{ }^{\circ} \mathrm{C}$. After the DNA was pelleted by centrifuging at $13,000 \mathrm{rpm}$ for $1 \mathrm{~min}$, the supernatant was discarded and the pellet was gently washed with $70 \%$ 
ethanol and resuspended in $20 \mu \mathrm{L}$ distilled water. The DNA was stored at $-20^{\circ} \mathrm{C}$ until further application.

DNA extraction employing organic solvents (Weiland, 1997)

Extraction buffer (100 mM Tris- $\mathrm{HCl} \mathrm{pH}$ 8.0, 20 mM EDTA, $0.5 \mathrm{M} \mathrm{NaCl}, 1 \%$ SDS) with a volume of $700 \mu \mathrm{L}$ was added into each tube containing grounded mycelia. Subsequently, $350 \mu \mathrm{L}$ of phenol: chloroform: isoamylalcohol $(25: 24: 1)$ was added to the mixture. The solution was mixed thoroughly and centrifuged at 13,000 $\mathrm{rpm}$ (room temperature) for $5 \mathrm{~min}$. Aqueous layer was transferred into new tubes and 0.6 volume of isopropanol was added. The tube was incubated at room temperature for $10 \mathrm{~min}$ and centrifuged at $13,000 \mathrm{rpm}, 4{ }^{\circ} \mathrm{C}$ for $15 \mathrm{~min}$. After centrifugation, the pellet was rinsed with $95 \%$ ethanol and resuspended in $340 \mu \mathrm{L}$ of TE $(10 \mathrm{mM}$ Tris$\mathrm{HCL}, 1 \mathrm{mM}$ EDTA) containing RNase A $(20 \mu \mathrm{g} / \mathrm{ml})$. The mixture was incubated at $37{ }^{\circ} \mathrm{C}$ for $30 \mathrm{~min}$ and extracted with $0.3 \mathrm{~mL}$ phenol: chloroform: isoamylalcohol (25:24:1). The aqueous phase was transferred into new tubes and half volume of $7.5 \mathrm{M}$ ammonium acetate and 2.5 volume of ethanol were added and mixed. The mixture was precipitated at $-20{ }^{\circ} \mathrm{C}$ for $30 \mathrm{~min}$ and after centrifugation, the pellet was rinsed with $95 \%$ ethanol, air dried and resuspended in distilled water.

\section{RNA isolation}

\section{RNA extraction using TRI REAGENT solution}

Approximately $5 \mathrm{ml}$ of TRI REAGENT solution (Molecular Research Center, USA) was added to $1 \mathrm{~g}$ of the mycelial powder. This reagent contains a mixture of guanidine thiocyanate and phenol solution. The homogenates were briefly vortexed, incubated at room temperature for $5 \mathrm{~min}$ and were aliquoted into $1.5 \mathrm{~mL}$ tubes followed by addition of $0.2 \mathrm{ml}$ chloroform for every $1 \mathrm{~mL}$ of TRI REAGENT ${ }^{\circledR}$ solution. The tubes were shaken vigorously for $1 \mathrm{~min}$, incubated at room temperature for $15 \mathrm{~min}$ followed by centrifugation at $12,000 \mathrm{~g}$ for $15 \mathrm{~min}$ at $4{ }^{\circ} \mathrm{C}$. This is the phase separation step whereby the mixtures were separated into phenol-chlorofom phase, interphase and aqueous phase. The RNA, which remains exclusively in the aqueous phase, was transferred into a new eppendorf tube before precipitated with $0.5 \mathrm{~mL}$ of cold isopropanol for $10 \mathrm{~min}$. After centrifugation at $12,000 \mathrm{~g}$ for $8 \mathrm{~min}$ at 4 ${ }^{\circ} \mathrm{C}$, the pellet was washed with $1 \mathrm{~mL} 75 \%$ cold ethanol and centrifuged for another $5 \mathrm{~min}$ at the same speed and temperature as the previous round. The pellet was then dried and dissolved in $20 \mu \mathrm{L}$ RNase-free water at $60^{\circ} \mathrm{C}$ for $10 \mathrm{~min}$. The RNA was kept at $-20^{\circ} \mathrm{C}$ until further usage.

RNA extraction using phenol and $\mathrm{LiCl}$ precipitation (Sokolovsky et al., 1990)

Powdered mycelia were homogenized in $0.75 \mathrm{~mL}$ lysis buffer $(0.6 \mathrm{M} \mathrm{NaCl}, 10 \mathrm{mM}$ EDTA, $100 \mathrm{mM}$ Tris-HCl pH $8.0,4 \%$ SDS). An equal volume of phenol was added into a tube and vortexed for 15 min followed by centrifugation at $13000 \mathrm{rpm}$ and $4{ }^{\circ} \mathrm{C}$ for $10 \mathrm{~min}$. The aqueous layer was transferred into a new tube containing an equal volume of phenol. After centrifugation for $10 \mathrm{~min}$ at $10,000 \mathrm{rpm}$ and $4{ }^{\circ} \mathrm{C}$, the aqueous layer was transferred into a new tube that contained 0.75 volumes of $8 \mathrm{M} \mathrm{LiCl}$ and stored overnight at $4{ }^{\circ} \mathrm{C}$ for RNA precipitation. The pellet was dissolved in 0.3 volume RNase free water and both 0.03 $\mathrm{mL} 3 \mathrm{M}$ sodium acetate $(\mathrm{pH} 5.2$ ) and $0.75 \mathrm{~mL} 100 \%$ ethanol were added into each tube. RNA was precipitated by incubation at $-20{ }^{\circ} \mathrm{C}$ for $2 \mathrm{~h}$. After centrifugation, the pellet was washed with $70 \%$ ethanol, air dried and dissolved in $20 \mu \mathrm{L}$ of RNase free water.

\section{Quantification and visualization of DNA and RNA}

The concentration and quality of isolated DNA and RNA was determined using spectrophotometer (Eppendorf, Germany) by measuring the absorbance at $260 \mathrm{~nm}$. The presence of protein and carbohydrate or polyphenol contaminations was determined by measuring the UV absorbance ratio of $A_{260 / 280}$ and $A_{260 / 230}$ respectively. The integrity of the DNA was visualized by electrophoresis in the ethidium bromide stained agarose gel $(1 \% \mathrm{w} / \mathrm{v})$. The integrity of RNA was checked by performing gel electrophoresis on a $1.3 \%$ agarose-formaldehyde gel in MOPS running buffer (20 mM MOPS, $5 \mathrm{mM}$ sodium acetate, $1 \mathrm{mM}$ EDTA, $\mathrm{pH}$ 7.0) and by electrophoresis in ethidium bromide stained agarose gel $(1 \% \mathrm{w} / \mathrm{v})$.

\section{PCR amplification}

The PCR amplification mixture consisted approximately $100 \mathrm{ng}$ of genomic DNA, 20 pmol of each primer, $2.5 \mathrm{mM}$ $\mathrm{MgCl}_{2}, 0.225 \mathrm{mM}$ of each dNTP (deoxynucleotide triphosphate) and $1 \mathrm{U}$ Taq DNA polymerase (Promega, USA). PCR was performed using the following parameters: $95{ }^{\circ} \mathrm{C}$ for $5 \mathrm{~min}(1 \mathrm{cycle}) ; 95^{\circ} \mathrm{C}$ for $20 \mathrm{sec}$, $57.5^{\circ} \mathrm{C}$ for $30 \mathrm{sec}$ and $72{ }^{\circ} \mathrm{C}$ for $1 \mathrm{~min}$ (29 cycles); and extension at $72{ }^{\circ} \mathrm{C}$ for 20 min ( 1 cycle). The forward and reverse primers used were specific to a gene that encodes for $C$. bainieri $\Delta 6$-fatty acid desaturase (des6); forward primer: 5'-TTGGTGGAACGACAAGCA-3'and reverse primer: 5'-AAATGATGGACGGCCTGG-3', with an expected PCR amplification product of $480 \mathrm{bp}$. The amplified product was analysed by gel electrophoresis on a $1.5 \%$ agarose gel containing $10 \mathrm{mg} / \mathrm{ml}$ of ethidium bromide and visualized under UV light. To confirm the identity, amplicons were gel purified and cloned into pGEMT-Easy vector (Promega). The insert of selected recombinant clones was sequenced by using SP6 and T7 primers.

\section{Restriction enzyme digestion and Southern blot analysis}

Approximately $2 \mu \mathrm{g}$ of genomic DNA was mixed with $1 \mu \mathrm{g}$ bovine serum albumin, $20 \mathrm{U}$ of restriction enzymes (BamHI, HindIII, Pstl and Kpnl: Promega) and $2 \mu \mathrm{L}$ of $10 \mathrm{X}$ buffer (supplied with the enzymes) in a total volume of 20 
$\mu \mathrm{L}$. The entire digestion mixture was loaded into $1 \% \mathrm{w} / \mathrm{v}$ agarose gel and electrophoresis was performed at $80 \mathrm{~V}$ for $1 \mathrm{~h}$. Subsequent steps for Southern blotting was performed as described by Sambrook and Russel (2001) with $670 \mathrm{bp}$ of $\Delta 12$-fatty acid desaturase gene (des12) fragment used as probe. The PCR product of des 12 was gel purified and labeled with $\left[\alpha{ }^{32} P\right] d C T P$ using a DNA Labeling System (Amersham, USA), and subsequently used to probe the digested DNA fixed onto the nylon membrane. Prehybridisation and hybridization were performed at $65^{\circ} \mathrm{C}$ using phosphate buffer containing $1 \mathrm{M}$ $\mathrm{Na}_{2} \mathrm{HPO}_{4}, 1 \mathrm{M} \mathrm{NaH}_{2} \mathrm{PO}_{4}, 0.5 \mathrm{M}$ EDTA and $7 \%$ (w/v) SDS. Following hybridization, the membrane was washed twice with 2 X SSC and $1 \%(\mathrm{w} / \mathrm{v})$ SDS for $10 \mathrm{~min}$ at $65^{\circ} \mathrm{C}$ and twice with $1 \times$ SSC and $1 \%(w / v)$ SDS for $10 \mathrm{~min}$ at $65^{\circ} \mathrm{C}$. Finally, the membrane was removed from the hybridisation bottle, sealed in a polythene bag and exposed to X-ray film in an autoradiograph cassette at -80 ${ }^{\circ} \mathrm{C}$ for 24 hours.

\section{Reverse-transcriptase PCR (RT-PCR)}

For the RT-PCR analysis, $50 \mathrm{ng}$ of RNA was reversetranscribed using Access ${ }^{\circledR}$ RT-PCR kit (Promega) using the following parameters: $48{ }^{\circ} \mathrm{C}$ for $45 \mathrm{~min}$ (reverse transcription step), $94^{\circ} \mathrm{C}$ for 2 min (reverse transcriptase inactivation), followed by : $95^{\circ} \mathrm{C}$ for $5 \mathrm{~min}(1 \mathrm{cycle}) ; 95^{\circ} \mathrm{C}$ for $20 \mathrm{sec}, 65^{\circ} \mathrm{C}$ for $30 \mathrm{sec}$ and $72{ }^{\circ} \mathrm{C}$ for $1 \mathrm{~min}(39$ cycles); and extension at $72{ }^{\circ} \mathrm{C}$ for $20 \mathrm{~min}$ ( 1 cycle). The forward and reverse primers used were designed to amplify des12 gene that encodes for $C$. bainieri $\Delta 12$-fatty acid desaturase; forward primer: 5' CGTAGTCGCATGCTCCCGGTC-3' and reverse primer: 5'GGAGGGTGGGATCGGTGTGC-3', with an expected PCR amplicon of $618 \mathrm{bp}$. The amplified product was then analysed by gel electrophoresis on a $1.5 \%$ agarose gel containing $10 \mathrm{mg} / \mathrm{mL}$ of ethidium bromide and visualized under UV light. The product was then gel purified, cloned and sequenced to completion to confirm its sequence identity.

\section{RESULTS AND DISCUSSION}

\section{Analysis of different DNA isolation protocols}

In this work we compared several protocols for efficient DNA and RNA isolation from an oleaginous fungus, $C$. bainieri strain 2a1. The establishment of suitable DNA and RNA isolation protocols that can produce high yields of genetic materials with minimal contaminants from this fungus is an important starting point for subsequent molecular genetic studies. Since this fungus is a potential producer of GLA, molecular genetic studies, for example, differential gene expression of desaturases, the group of enzymes responsible for increasing the degree of fatty acid desaturation, will provide useful information on cellular events that take place during GLA production in fungi.

The four DNA extraction methods selected for this study were based on different, but commonly used, plant
(Pich and Schubert, 1993; Kim et al., 1997) and fungal (Weiland, 1997; Voigt et al., 1999) cell lysis procedures. Protocols developed by Pich and Schubert (1993) (will be referred to as Pich \& Schubert method hereafter) and Kim et al. (1997) (will be referred to as Kim method hereafter) used PVP, which can form complexes with secondary products such as polyphenolics thus preventing the latter from binding to DNA after cell lysis. However, the Pich \& Schubert method requires several precipitation and centrifugation steps to separate DNA from the PVP complex. The Kim method, on the other hand, was an improved version of Pich \& Schubert method, whereby the requirement for excessive precipitation and centrifugation steps has been simplified. Protocols used by Voigt et al. (1993) (will be referred to as Voigt method hereafter); on the other hand, used CTAB which can remove unwanted carbohydrates from the DNA preparation. The protocol described by Weiland (1997) (will be referred to as Weiland method hereafter), however, was relatively quick and less expensive as only conventional solvents (phenol, chloroform and isoamylalcohol) were used to extract genomic DNA.

Table 1: Comparison of yield and quality from various methods of DNA extraction. All values are means of triplicate determination

\begin{tabular}{lccc}
\hline \multicolumn{1}{c}{ Methods } & $\begin{array}{c}\text { DNA yield } \\
(\boldsymbol{\mu} \mathbf{g} / \mathbf{g} \\
\mathbf{m y c e l i a})\end{array}$ & $\mathbf{A}_{260 / 280}$ & $\mathbf{A}_{260 / 230}$ \\
& & & \\
\hline Pich \& Schubert & $633 \pm 30.3$ & $1.43 \pm 0.079$ & $1.89 \pm 0.12$ \\
method & $392 \pm 6.0$ & $1.28 \pm 0.160$ & $1.68 \pm 0.67$ \\
Kim method & $532.1 \pm 13.8$ & $1.23 \pm 0.090$ & $1.77 \pm 0.43$ \\
Weiland method & $816 \pm 12.2$ & $1.67 \pm 0.640$ & $1.97 \pm 0.23$ \\
Voigt method & & & \\
\hline
\end{tabular}

Table 1 shows the yield and quality of $C$. bainieri DNA isolated using different protocols. Results from three independent DNA extraction showed that the protocol of Voigt method produced the highest yield of DNA, producing an average of $816 \pm 12.2 \mu \mathrm{g} D N A / g$ of mycelia followed by Pich and Schubert method which produced $633 \pm 30.3 \mu \mathrm{g} \mathrm{DNA} / \mathrm{g}$ of mycelia. The quality of DNA isolated by the Voigt method was also relatively better than the other three protocols. It produced the best UV absorbance ratio for protein contamination $\left(\mathrm{A}_{260 / 280}\right)$ and carbohydrate contamination $\left(\mathrm{A}_{260 / 230}\right)$ (Table 1$)$. However, these values still indicate that a small amount of protein and carbohydrate contamination may be present in the genomic DNA since the ratios of $A_{260 / 280}$ was lower than 1.8 and $A_{260 / 230}$ was slightly lower than 2.0. For a good and clean preparation of nucleic acid, the $A_{260 / 280}$ ratio, which represent protein contamination, should be between 1.8 to 2.0 while the $A_{260 / 230}$ ratio, which represent carbohydrate contamination, should be more than 2.0 (Sambrook and Russel, 2001).

To test the suitability of the extracted DNA for enzymatic reactions, PCR was carried out using primers designed to amplify a $480 \mathrm{bp}$ amplicon of a gene encoding 
for $C$. bainieri $\Delta 6$-fatty acid desaturase (des6) gene. Genomic DNA extracted using all four protocols was used as template for PCR amplification. Figure 1 shows that all of DNA samples, with the exception of genomic DNA extracted via the Kim method could be used to amplify des 6 fragment. This indicates that all three protocols were able to produce a relatively good quality DNA that is suitable for PCR reaction. The failure to amplify the targeted gene from DNA extracted using Kim method may be due to the presence of impurities in the genomic DNA that interfered with the PCR reaction.



Figure 1: $P C R$ products of des 6 amplified using genomic DNA extracted via different protocols as template. Lane M: 100 bp DNA marker; lane 1: DNA extracted via Voigt method; lane 2: DNA extracted via Pich \& Schubert method; lane 3: DNA extracted via Weiland method; and lane 4: DNA extracted via Kim method

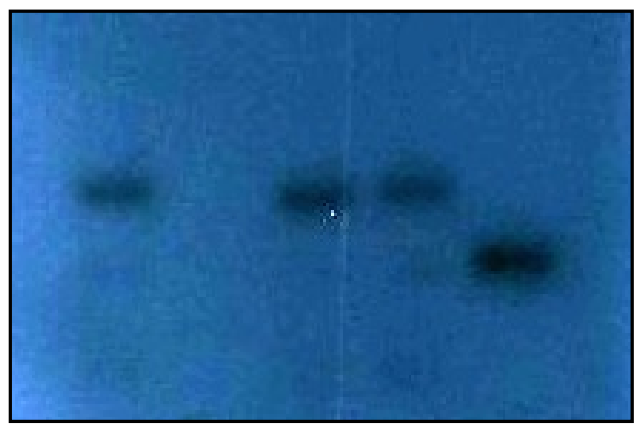

Figure 2: Southern blot hybridisation using des12 fragment (670 bp) as probe and DNA extracted by Voigt method. Lane 1: genomic DNA digested with BamHI; lane 2: genomic DNA digested with HindIII; lane 3: genomic DNA digested with $K p n l$ and lane 4: genomic DNA digested with Pstl

Since genomic DNA extracted by the Voigt method produced the highest yield and relatively good quality
DNA, we tested the DNA for restriction enzyme digestion and verified the results via Southern blotting. The genomic DNA was digested with four common restriction enzymes, $B a m H I$, HindlII, Kpnl and Pstl. Figure 2 shows the autoradiographic signals detected when the nylon membrane containing the DNA was probed with a gene fragment encoding $C$. bainieri $\Delta 12$-fatty acid desaturase (des12). The intact bands obtained from this analysis indicates that $C$. bainieri genomic DNA extracted via Voigt method yielded good quality DNA that could be efficiently digested with restriction enzymes.

\section{Analysis of different protocols for RNA isolation}

In this work, we examined the suitability of two methods for the isolation of total RNA, which were previously untested for $C$. bainieri. One procedure is based on the addition of TRI REAGENT ${ }^{\circledR}$ solution, which combines guanidine thiocyanate and phenol in a single solution and the extraction procedure employing RNA isolation protocol initially described by Chomzynski and Sacchi (1987). In our laboratory, this solution is extensively used for RNA extraction from other fungi and when compared to other techniques its procedure can be completed in the shortest time. The second method, using a protocol first described by Sokolovsky et al. (1990) (will be referred as Sokolovsky method hereafter), combines phenol extraction and $\mathrm{LiCl}$ precipitation. This method was shown to produce high quality of total RNA with relatively high yields.

A

B

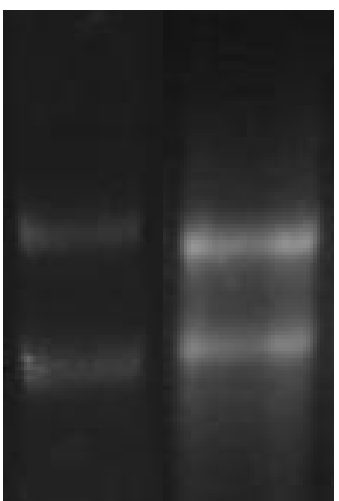

Figure 3: Total RNA extracted using (A) Tri Reagent solution and (B) Sokolovsky method was electrophoresed on $1 \%$ formaldehyde gel

Figure 3 shows the results of the gel electrophoresis of total RNA extracted from mycelia of $C$. bainieri using TRI REAGENT ${ }^{\circledR}$ and Sokolovsky method. The ethidium bromide stained formaldehyde gel showed two distinct bands of $28 \mathrm{~S}$ and $18 \mathrm{~S}$ ribosomal RNA, indicating that both methods could isolate intact RNA from the mycelia of $C$. bainieri. In addition, no traces of genomic DNA can be detected when both samples were run on ethidium 
Mal. J. Microbiol. Vol 3(1) 2007, pp. 7-13

bromide stained agarose gel (data not shown), indicating that both protocols resulted in the efficient isolation of RNA from genomic DNA. Purity of the extracted RNA was analyzed using spectrophotometer.

Table 2: Comparison of yield and quality of RNA extracted from two methods of RNA isolation

\begin{tabular}{lccc}
\hline \multicolumn{1}{c}{ Method } & $\begin{array}{c}\text { RNA yield } \\
(\boldsymbol{\mu} \mathbf{g} / \mathbf{g} \\
\mathbf{m y c e l i a})\end{array}$ & $\mathbf{A}_{\mathbf{2 6 0 / 2 8 0}}$ & $\mathbf{A}_{\mathbf{2 6 0 / 2 3 0}}$ \\
\hline & & & \\
\hline $\begin{array}{l}\text { TRI REAGENT } \\
\begin{array}{l}\text { Sokolovsky } \\
\text { method }\end{array}\end{array}$ & $253 \pm 1.9$ & $1.78 \pm 0.09$ & $2.01 \pm 0.1$ \\
\hline
\end{tabular}

The average yield and purity was determined from three different RNA extractions for each method. The spectrophotometrically determined yields of RNA are given in Table 2. The data show that the Sokolovsky method yielded higher RNA as compared to the TRI REAGENT protocol. The average concentration of total RNA isolated by the Sokolovsky method was $372 \pm 6.0$ $\mu \mathrm{g} / \mathrm{g}$ mycelia as compared to $253 \pm 1.9 \mu \mathrm{g} / \mathrm{g}$ mycelia produced using the TRI REAGENT protocol. In addition, the Sokolovsky method yielded higher quality RNA. The UV absorbance A260/A280 and A260/A230 ratios for RNA extracted via the Sokolovsky protocol were well within the acceptable range of $1.80-2.0$ and 2.0 respectively (Table 2). Polysaccharide contamination is a consistent hindrence in extracting good quality fungal genetics materials. This is due to the presence of high content of polysaccharides in fungal cell walls (Gow and Gadd, 1995). However, both methods show spectrophotometric ratio $260 / 230 \mathrm{~nm}$ of approximately two, indicating the absence or low levels of polysaccharide contamination. In addition, the RNA isolated via Sokolovsky method was also free from protein contamination as the $A_{260 / 280}$ ratio was well within the accepted range of 1.8-2.0. A very low contamination of protein may be present in the RNA sample isolated via the TRI REAGENT solution as the $A_{260 / 280}$ ratio was slightly lower than 1.8 .

\section{Reverse Transcriptase PCR (RT-PCR)}

Since the Sokolovsky method produced the highest yield of RNA with high purity, we tested the suitability of RNA extracted using this protocol for reverse transcriptase PCR (RT-PCR). In this work, the des12 was reversed transcribed and amplified using the extracted RNA as template. Figure 4 shows that a 618 bp amplicon was produced by the RT-PCR. The amplified product was cloned and sequence analysis has confirmed the $618 \mathrm{bp}$ sequence of des12. The amplification of the product suggests that the RNA extracted via Sokolovsky method was essentially free of contaminants that could inhibit enzymatic reactions and suitable for RNA profiling techniques.

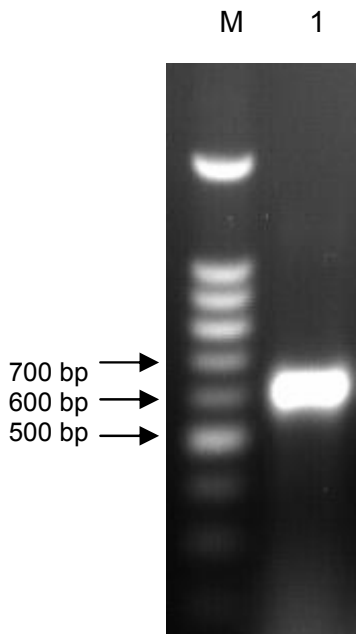

Figure 4: RT-PCR analysis using RNA extracted from Sokolovsky method. M: 100 bp DNA marker; Lane 1: des12 amplicon using $1 \mu \mathrm{g}$ of total RNA

\section{CONCLUSION}

In summary our results show that, among the four DNA extraction methods analyzed, the Voigt method is the most suitable method for DNA extraction from the oleaginous fungus $C$. bainieri. This method produced the highest yield of genomic DNA suitable for molecular genetic analyses such as PCR and Southern blot analysis. Similarly, Sokolovsky method is an effective method to extract RNA from $C$. bainieri. This method produced high yield and quality of RNA that could be utilized for other RNA profiling techniques.

\section{ACKNOWLEDGEMENTS}

The authors would like to thank the financial support from the National Biotechnology Directorate, MOSTI for the financial support through grant no. 09-02-02-001 BTK/TD/001.

\section{REFERENCES}

Al-Samarrai, T.H. and Schmid, J. (2000). A simple method for extraction of fungal genomic DNA. Letters in Applied Microbiology 30: 53 - 56.

Bolano, A., Stinchi, S., Preziosi, R., Bistoni, F., Allegrucci, M., Baldelli, F., Martini, A. and Cardinali, G. (2001). Rapid methods to extract DNA and RNA from Cryptococcus neoformans. FEMS Yeast Research 1: 221 - 224.

Certik, M. and Shimizu, S. (1999). Biosynthesis and regulation of microbial polyunsaturated fatty acid production. Journal of Biosciences and Bioengineering 87: 1 - 14.

Chomczynski, P. and Sacchi, N. (1987). Single-step method of RNA isolation by acid guanidinium 
thiocyanate-phenol-chloroform extraction Analytical Biochemistry 162: 156 - 159.

Hamid, A.A., Yusof, W.M.W., Illias, R.M. and Nadarajah, K. (2001). Pengasingan strain baru kulat dari tanah Malaysia untuk penghasilan asid $\gamma$ linolenik (GLA). Jurnal Teknologi 34: 1 - 8.

Lawson, L.D. and Hughes, B.G. (1988). Triacylglycerol structure of plant and fungal oils containing $\gamma$-linolenic acid. Lipids 23: 313 - 317.

Fan, Y.Y. and Chapkin, R.S. (1998). Importance of dietary $\gamma$-linolenic acid in human health. Journal of Nutrition 128: 1411 - 1414.

Ferjani, E.A., Murad, A.M.A., Wan Mohtar, W.Y., Aidil, A.H., Mahadi, N.M. and Farah Diba, A.B. (2005). Determination of the rate limiting step for gamma-linolenic acid biosynthesis in Cunninghamella sp 2a1. Proceedings of the 27th Symposium of the Malaysian Society for Microbiology, Penang, Malaysia. pp 97-99.

Kendrick, A. and Ratledge, C. (1992). Lipids of selected molds grown for production of $n-3$ and $n-6$ polyunsaturated fatty acids Lipids 27: $15-20$.

Kim, C.S., Lee, C.H., Shin, J.S., Chung, Y.S. and Hyung, N.I. (1997). A simple and rapid method for isolation of high quality genomic DNA from fruit trees and conifers using PVP. Nucleic Acids Research 25: 1085 - 1086.

Mukhtar, M., Parveen. Z. and Logan, D.A. (1998). Isolation of RNA from the filamentous fungus Mucor circinelloides. Journal of Microbiological Methods 33: 115 - 118.

Pich, U. and Schubert, I. (1993). Midiprep method for isolation of DNA from plants with a high content of polyphenolics. Nucleic Acid Research 21: 3328.

Sambrook, J. and Russel, D.W. (2001). Molecular cloning: a laboratory manual. Third Edition. Cold Spring Harbor Laboratory Press. New York.

Sokolovsky, V., Kaldenhoff, R., Ricci, M. and Russo, V.E.A. (1990). Fast and reliable mini-prep RNA extraction from Neurospora crassa. Fungal Genetic Newsletter 37: 41 - 43.

Voigt, K., Cigelnik, E. and O'Donnell, K. (1999). Phylogeny and PCR identification of clinically important Zygomycetes based on nuclear ribosomal-DNA sequence data. Journal of Clinical Microbiology 37: 3957 - 3964.

Weiland, J.J. (1997). Rapid procedure for the extraction of DNA from fungal spores and mycelia. Fungal Genetics Newsletter 44: 60 - 66. 